\title{
THE JOURNAL OF
}
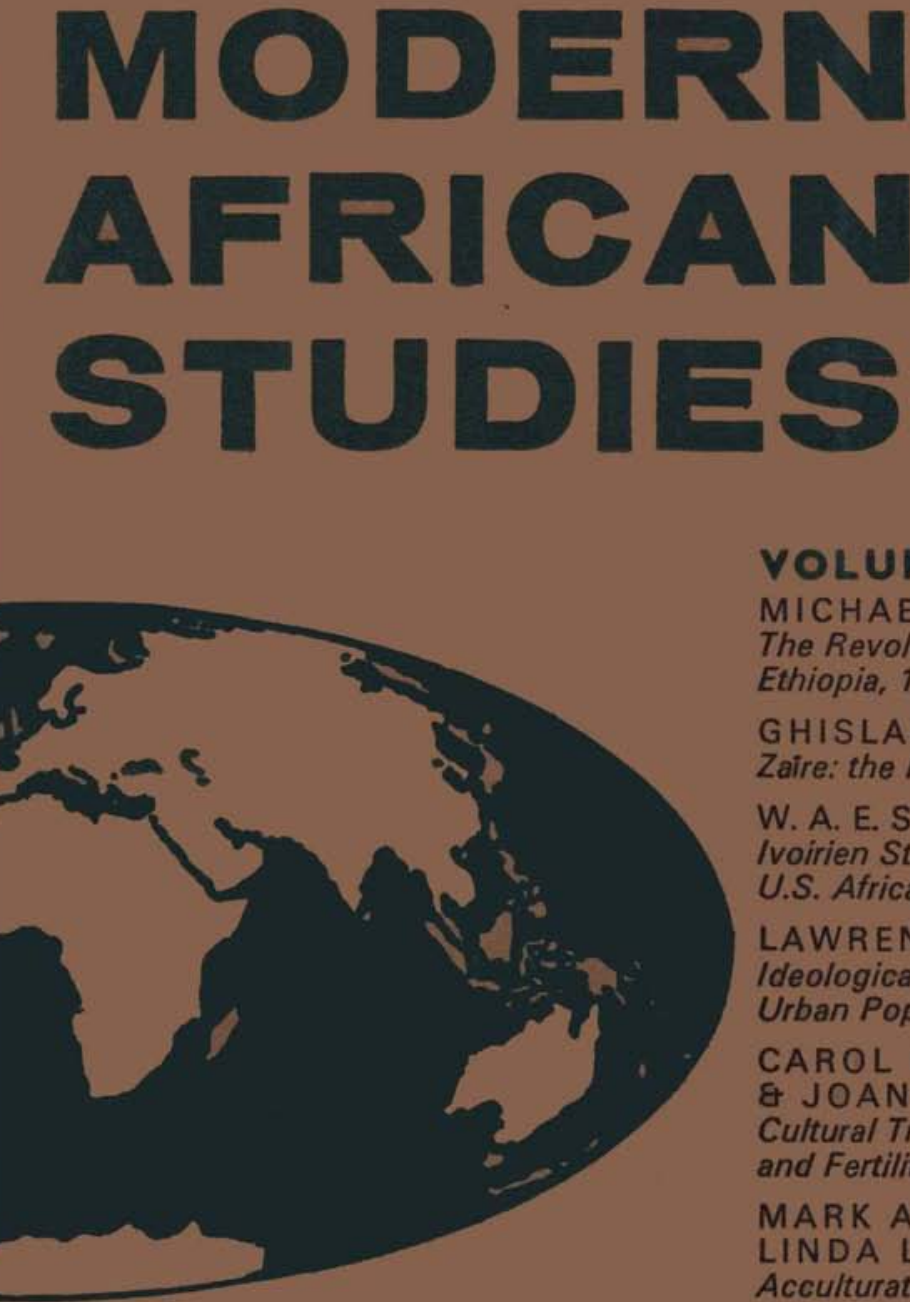

VOLUME 17 NUMBER 3 MICHAEL CHEGE The Revolution Betrayed:

Ethiopia, 1974-9

GHISLAIN C. KABWIT Zaire: the Roots of the Continuing Crisis W. A. E. SKURNIK Ivoirien Student Perceptions of U.S. Africa Policy

LAWRENCE P. FRANK Ideological Competition in Nigeria: Urban Populism versus Élite Nationalism CAROL HOPKINS VALENTINE \& JOANNE E. REVSON Cultural Traditions, Social Change, and Fertility in Sub-Saharan Africa MARK A. TESSLER \& LINDA L. HAWKINS Acculturation, Socio-Economic Status, and Attitude Change in Tunisia: Implications for Modernisation Theory

REVIEWS
A QUARTERLY SURVEY OF POLITICS, ECONOMICS \& RELATED TOPICS IN CONTEMPORARY AFRICA EDITED BY DAVID KIMBLE 


\section{EDITORIAL ADVISORY BOARD}

Jamal Moh ammed Aнмеd, Ministry of Foreign Affairs, Khartoum

Professor G. Balandier, Universite de Paris

Sir Kenneth Berrilt, Central Policy Review Staff, London

DR S. O. ВІов А KU, University of Ibadan

Dr B. T. G. Chidzero, U.N.C.T.A.D., Geneva

Professor J. S. Golesan, Université nationale du Zaîre, Kinshasa

Professor J. G. St Glair Drake, Stanford Univetsity

THOMAS HODGKIN, Unizersity of Oxford

Jorn Holmes, Canadian Institute of International Affairs, Toronto

HELEN KimBle, Oxford

Sir Arthur Lewis, Princeton University

Professor C. T. Leys, Queen's University, Kingston, Ontario

Dr ABdoulaye Ly, I.F.A.N., University of Dakar

TAI Ė B SLrm, Tunisian Ambassador to Morocco, Rabat

Dr V. G. Solodovinov, Africa Institule, Academy of Sciences, Mascow

Professor S. N. VARMA, University of 1 fe

\section{CONTRIBUTIONS}

Contributions are invited from all over the world, and especially from scholars working in African universities. Articles written in languages other than English will be considered on their merits, and where necessary translation will be arranged. The average length suggested is 4,000 to 6,000 words, with occasional exceptions of up to 10,000 words. Initially, one coby should be submitted, and not the original typescript.

All correspondence and contributions should be addressed to

DR DAVID KIMBLE, Editor of the J.M.A.S., Vice-Chancetlor of the University op Malawi, P.O. Box 278, ZомвA, MAI.AWI.

Each contributor will receive a copy of the number and 2.5 offprints of his article free of charge.

Contributors to this Journal express their own opinions, which should not be interpreted as the official view of any institution or organisation with which they may be connected.

\section{SUBSCRIPTIONS}

The Journal of Modern African Studies (ISSN: $0022-278 \mathrm{x}$ ) is published quarterly by Cambridge University Press, P.O. Box 110 , Cambridge $\mathrm{CB}_{2}{ }_{3} \mathrm{RL}$, and 32 East $57_{\text {th }}$ Street, New York, N.Y. 10022.

Single parts cost 66.00 (US $\$ 15.00$ in the U.S.A. and Canada) plus postage. Four parts form a volume. The subscription price (which includes postage) of volume 17,1979 , is $\$ 19.00$ net (US $\$ 46.50$ in the U.S.A. and Canada) for institutions, $\ell_{9.50}$ (US $\$ 2$ 5.00) for individuals ordering direct from the publishers and certifying that the Journal is for their personal use.

Orders, which must be accompanied by payment, may be sent to a bookseller or to the publishers (in the U.S.A. and Canada to the New York Office).

Copies of the Journal for subseribers in the U.S.A. and Canada are sent by air to New York to arrive with minimum delay. Second-class postage is then paid. Postmaster : send address changes in U.S.A. and Canada to Cambridge University Press, 32 East 57 th Strect, New York, N.Y. 10022.

Claims for missing issues will only be considered if made immediately on receipt Published online by Cambridge University Press
of the subsequent 1 sstue. 


\section{ARTICLES}

THE REVOLUTION BETRAYED: ETHIOPIA, 1974-9

Dr Michael Ghege, Senior Lecturer in Government and Director of the Diplomacy Training Programme, University of Nairobi

ZAIIRE: THE ROOTS OF THE CONTINUING CRISIS

Dr Ghislain C. Ka Bwit, Assistant Professor of Political Science, University of Maryland, Eastern Shore, Princess Anne, Maryland

IVOIRIEN STUDENT PERGEPTIONS OF

U.S. AFRICA POLIGY

DR W. A. E. SKuRNIK, Professor of Political Science, University of Colorado, Boulder

IDEOLOGICAL COMPETITION IN NIGERIA: URBAN

POPULISM VERSUS ELITE NATIONALISM

Dr Lawrence P. Frank, Assistant Professor of Government, St Lawrence University, Canton, New York

CULTURAL TRADITIONS, SOCIAL GHANGE, AND FERTILITY IN SUB-SAHARAN AFRICA

Carol Hopkins Valentine, Consultant to the United Nations Fund for Population Activities, and JoAnne E. Revson, Senior Staff Associate, Centre for Population and Family Health, College of Physicians and Surgeons of Colombia University, New Tork

AGCUMULATION, SOGIO-EGONOMIC STATUS, AND ATTITUDE GHANGE IN TUNISIA: IMPLICATIONS FOR MODERNISATION THEORY

Dr Mark A. Tessler, Professor of Political Science, and Linda L. HawkIns, Specialist, Social Science Research Facility, The University of Wisconsin, Milwaukee

\section{REVIEWS}

Roots of a Revolution: scenes from Zimbabwe's struggle by NDAB AN IN G I SiTHor.E DR F E I O O-ADE, Department of Modern European Languages, University of Ife, Ile-Ife

Rezolution and the Transformation of Societies: a comparative study of civilizations by

S. N. EISENSTADT

DR P. F. WILMOT, Department of Sociologv, Ahmadu Bello University, Zaria

The International Economy and the Undeveloped World, $1865-1914$ by A. J. H. LA T HAM KWAsi Kwartenc, Office of the Trade Adviser, Commonwealth Secretariat, Geneva 
Africa's Industrial Future by RICHARD BAILEY

$D_{R}$ W. A. NDong Ko, Department of Economics, University of Calabar, Nigeria

Zambia: impact of industrial strategy on regional imbalance and social inequality by

M. R. BhaGaVAN

Dr Roger TANGrI, Department of Political and Administrative Studies, University of Zambia, Lusaka

The Growth of East African Exports and their Effect on Economic Development by

LESLIE STEIN

DR M. S. Silve R, Management Centre, The University of Aston, Birmingham

Mines, Masters and Migrants: life in a Namibian mine compound by ROBERT J. Gordon

Dr Richard Dale, Department of Political Science, Southern Illinois University, Carbondale

Housing the Urban Poor in Africa: policy, politics, and bureaucracy in Mombasa by RIGHARD E. STREN

DR C. P. LE O, Department of Political Science, The University of Winnipeg

Self Reliance and Foreign Policy in Tanzania: the dynamics of the diplomacy of a new state, 1961 to 1971 by OKWUDIBA NNOLI

Dr Tim от нy M. Sha w, Department of Political Science, Carleton University, Ottawa, and Dalhousie University, Halifax, Nova Scotia

Politics, Languages, and Thought: the Somali experience by DAvid D. LAIrIN

A в I S SEIK-Aв DI, Department of History and the African Studies Program, Boston University

The International Politics of the Nigerian Civil War, $1967-1970$ by John STre mLAu

Africa Reports on the Nigerian Crisis: news, attitudes and background information-a study of press performance, government attitude to Biafra and ethno-political integration by

HeNRYKa SGHa BOWSKa and ULF Himmelstrand

Professor Sang-Seg r Park, Department of Political Science, Hampton Institute, Virginia

The Unfinished Quest for Unity: Africa and the $O A U$ by ZDENE X CERVENKA

Dr Richard A. Fred dand, Department of Political Science, Indiana and Purdue University at Indianapolis

Management in South Africa: introductory text by P. A. MILLER

Theories of Management and the Executive in the Developing World by U. G. DA м A снI Management Education in Africa - Appraisal and Prospectus: selected papers and discussion from an intermational conference held at the East African Community Management Institute, 23rd to 26th November 1976

Peter Rutherford, Department of Management Studies, The Polytechnic, University of Malawi, Blantyre

The Korsten Basketmakers: a study of the Masoze Apostles, an indigenous African religious movement by Give M. Dil LoN-MA LONE

Dr K. Ny amayaro Mufura, Department of Social Studies, Lander College, Greenwood, South Carolina

The Jamaa and the Church: a Bantu Catholic movement in Zaire by Wille De Graemer

DR STAN LEY R. BA RR T T, Department of Sociology and Anthropologv, University of Guelph, Ontario 